J. Perinat. Med. 16 (1988) 447

\title{
In-vivo NMR spectroscopy of the fetal lung in guinea-pigs
}

\author{
Klaus Langner', Joachim W. Dudenhausen', Stephan Schmidt', Erich Z. Saling', \\ Rolf Herbst $^{2}$, Hartmut Friedberg ${ }^{3}$, Dieter Höpfel ${ }^{4}$ \\ ${ }^{1}$ Institute of Perinatal Medicine and ${ }^{2}$ Institute of Pathology, The Free University \\ of Berlin, West-Berlin, Germany, ${ }^{3}$ Institute of X-ray Diagnostics, The University \\ of Freiburg, West-Germany, and ${ }^{4}$ Bruker Medizintechnik GmbH, Rheinstetten, \\ West-Germany
}

\section{Introduction}

Whereas phosphor spectra have already been recorded of most organe and tissues using NMR invivo techniques [1], up to now no in-vivo spectrum of the fetal lung has been published in the literature. This may be explained by inherent difficulties to achieve in-vivo NMR investigations of the ventilated lungs after delivery.

In-vivo NMR imaging and NMR spectroscopy with the methods available today is only possible by using very sophisticated techniques. It is possible to make NMR in-vivo spectroscopy of the lung ante partum before the lungs are aerated. Direct access to the fetal lung can be achieved by using NMR in-vivo spectroscopy. Possible questions concerning fetal lung maturation treatment may be reached using this technique. The inherent limitations which occur when employing in-vitro studies for fetal lung maturity diagnostics can be avoided by using this method. A non-invasive biochemical analysis such as this provides continuous information concerning the biochemical process of the lung surfactant kinetics. We think that phosphor NMR spectroscopy can become a useful tool for studying the course of fetal lung maturation and its promotion. We have been successful in obtaining the very first in-vivo spectra of lung tissue in an animal model.

\section{Material and methods}

NMR-P31 in-vivo spectra of the fetal lungs were obtained from six guinea-pigs with a gestational age of 45 to 65 days. We used for our experiments

\section{Curriculum vitae}

Klaus Langner, D. Eng. was born in 1948 in Altenburg, Thüringen, Germany. He studied chemistry at the Technical University of Berlin from 1967 till 1973. He did research on physical chemistry from 19741980 at the Fritz Haber Institute of the Max-PlanckGesellschaft and in 1979 graduated in this field at the Technical University of Berlin (Doctor of Engineering). From 1974 to 1981 he studied medicine at the Free University of Berlin. Since 1981 he has been working as a physician and a researcher at the Institute of Perinatal Medicine of the Free University of Berlin and Department of Obstetrics, Women's Hospital Berlin-Neukölln. His main fields of interest are non-invasive fetal monitoring and infectious diseases.

Pirbright white guinea-pigs with a gestation period of 68 days on the average. The beginning of the oestrus can be stated by the disintegration of the vaginal membrane, this is day 0 of the pregnancy. The exact date, number of fetuses, weights and crown-rump-lengths as well as the gestational age can be seen in table I. We used a Bruker tomograph (BMT 24/30) at a field strength of $2.35 \mathrm{~T}$. A series of cross-sections of the pregnant guineapigs with a gestational age of $45-65$ days were obtained using the two-dimensional Fourier transform technique to localize the fetuses. For technical reasons there is an interval between the to- 
Table I. Data of the fetuses examined and corresponding to multiple pregnancies

\begin{tabular}{|c|c|c|c|c|}
\hline $\begin{array}{l}\text { Animal } \\
\text { No. }\end{array}$ & $\begin{array}{l}\text { Gestational age } \\
\text { in days }\end{array}$ & $\begin{array}{l}\text { Crown rump } \\
\text { length } \\
{[\mathrm{cm}]}\end{array}$ & $\begin{array}{c}\text { Weight } \\
{[\mathrm{g}]}\end{array}$ & $\begin{array}{l}\text { Number of } \\
\text { fetuses }\end{array}$ \\
\hline 1 & 45 & 7,6 & 24 & 2 \\
\hline 2 & 48 & 9,5 & 33 & 5 \\
\hline 3 & 53 & 10,0 & 46 & 3 \\
\hline 4 & 59 & 11,1 & 69 & 2 \\
\hline 5 & 62 & 12,2 & 74 & 3 \\
\hline 6 & 65 & 12,6 & 78 & 3 \\
\hline
\end{tabular}

mography and the spectroscopy, during which the fetus can alter its position. So, after laparotomy and uterotomy under ketamine/xylazine anaesthesia, the thorax of the fetus was fixed to the abdominal wall to allow the maintenance of the position of the fetal chest on the surface coil $(2 \mathrm{~cm}$ diameter) (figure 1). Such fixation of the fetal thorax will be superfluous in the future when NMR equipment becomes available that will provide imaging for localization and spectroscopy at an (electronically) preselected volume. Such NMR systems should permit the method to be applied to the human fetus. After NMR measurement the lungs of the guinea-pig fetuses were fixed by intratracheal instillation with a mixture of two parts of 7,5\% paraform-aldehyde and three parts of $5 \%$ glutaraldehyde, buffered at $\mathrm{pH} 7,3$ with $0,15 \mathrm{M}$ phosphate solution. The specimens were postfixed in $2 \%$ osmium tetroxide in the same buffer, dehydrated in graded alcohols and embedded in araldite about propylene oxide. The thin sections were collected on copper grids, stained with 5\% uranylacetate solution in $50 \%$ ethanol and Reynold's lead citrate, and examined with an EM 10 transmission electron microscope.

\section{Results}

P31-spectra recorded showed a typical course; the same peaks were repeatedly identifiable in all the guinea-pig lungs examined. In addition to the wellknown ATP and PCR, Pi peaks [1], a high peak (peak I) emerged in the phosphomonoester region with a chemical shift of about $6,5 \mathrm{ppm}$. There were also two further peaks (II, III) in the phosphodiester region with a chemical shift of 2 to $3 \mathrm{ppm}$ (figures 2 to 4). The comparison of the signals strength of the peaks of the compounds of ATP,

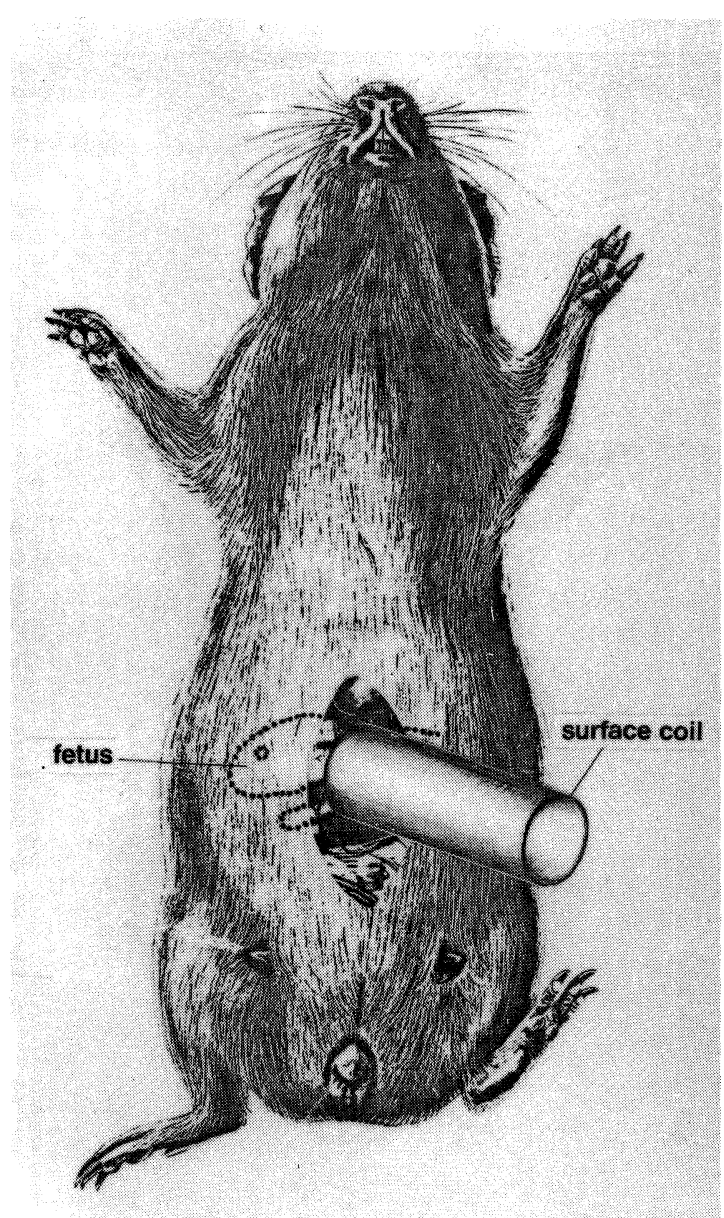

Figure 1. Schematic drawing showing the positioning of the surface coil directly on the fetal thorax in situ after laparotomy and uterotomy

PCR and Pi with the signal strength of peak I shows that the phosphorous compound represented by this peak must be present in a relatively high concentration in the fetal lung tissue. Peak II and III resonating in the phosphodiester region must also have considerable concentration in the fetal lung tissue. The ratio of the baseline corrected peak from peak I to the phosphorcreatinine peak or the anorganic phosphorus peak, shows that the relative signal intensity of peak I increases with advancing gestational age (table II). This means that the relative concentration of the compound represented by this peak increases with advancing gestational age. Peaks II and III are present in all 


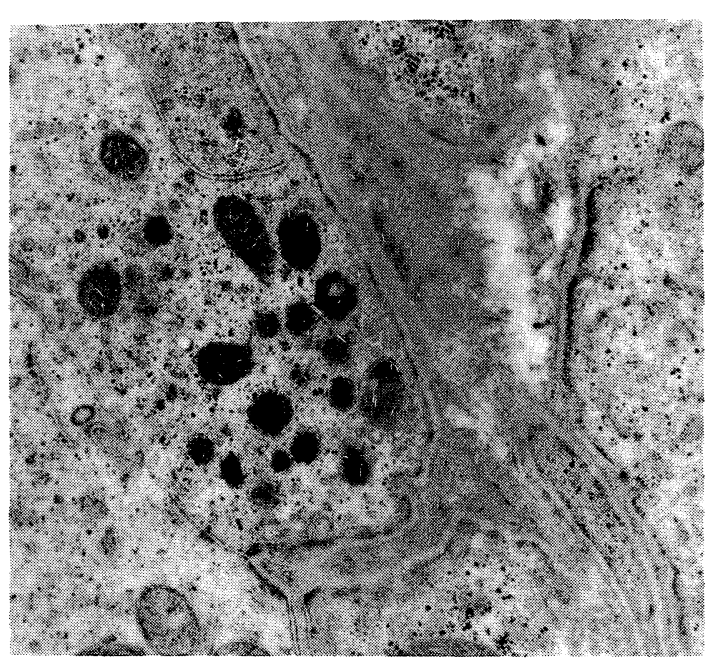

$\mathrm{PCr}$

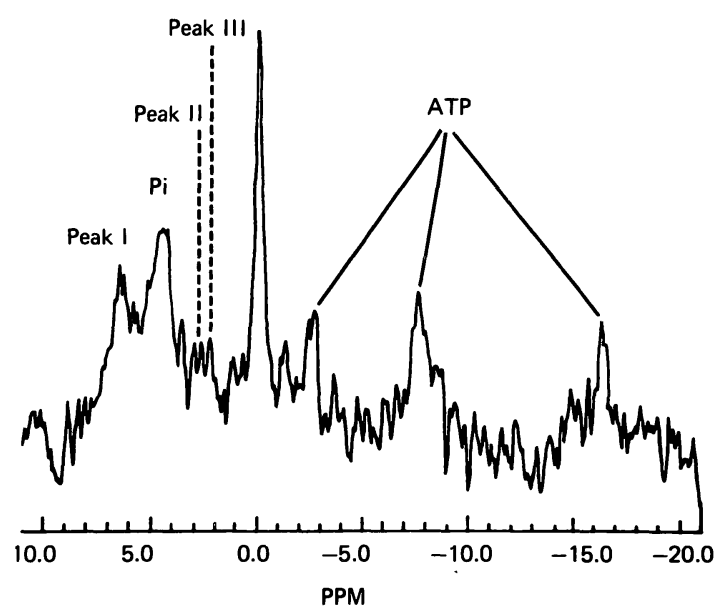

Figure 2. Phosphor 31 spectrum of lung tissue (b) of a 48 day-old guinea-pig fetus and the corresponding electron micrograph (a). Electron dense, homogenous granules in the pneumocyte type II are precursors of the lamellar bodies and demonstrate the beginning of lung maturation (Magnification 32000 :1)

the spectra regardless of the gestational age; however, we found no relation of the relative signal intensity to the gestational age.

After the recording of the NMR spectra, the fetuses were sacrificed, their lungs fixed and so it was possible to make electron microscopic examinations of the fetal lung tissue, and to compare them with the associated spectra.
Table II. Comparison of gestational age, morphological state of fetal lung maturity and relative signal intensity of peak I

\begin{tabular}{|c|c|l|c|c|}
\hline Animal & $\begin{array}{c}\text { Gestational age } \\
\text { (days) }\end{array}$ & $\begin{array}{l}\text { Electron mieroscopy } \\
\text { of the fetal lungs }\end{array}$ & $\begin{array}{l}\text { Relative signal } \\
\text { intensity: } \mathbf{P}_{\mathbf{I}} / \mathbf{P C r}\end{array}$ & $\begin{array}{c}\text { Relative signal } \\
\text { intensity: } \mathbf{P}_{\mathbf{I}} / \mathbf{P i}\end{array}$ \\
\hline 1 & 45 & no granules & 0.26 & 0.56 \\
\hline 2 & 48 & $\begin{array}{l}\text { homogeneous } \\
\text { granules }\end{array}$ & 0.49 & 0.86 \\
\hline 3 & 53 & $\begin{array}{l}\text { homogeneous } \\
\text { granules and } \\
\text { lamellar bodies }\end{array}$ & 0.57 & 0.86 \\
\hline 5 & 59 & $\begin{array}{l}\text { lamellar bodies and } \\
\text { surfactant } \\
\text { mature }\end{array}$ & 0.56 & 0.98 \\
\hline 6 & 62 & $\begin{array}{l}\text { lamellar bodies and } \\
\text { surfactant } \\
\text { mature }\end{array}$ & 0.55 & 1.06 \\
\hline
\end{tabular}

In the figures 2 to 4 you can see the electron micrographs of the fetal lungs and the corresponding spectra. Table II shows the date of the gestational age in comparison with the relative signal intensity of peak I and with the morphological state of fetal lung maturity.

The change from the canalicular to the terminal sac period arises at day 46 post conception (p.c.) during the guinea-pig's development. On day 45 p.c. the lungs are immature. The pneumoblasts include great glycogen deposits. The differentiation into pneumocytes type I and type II does not yet take place, also the cell organelles give no information on their prospective development.

On day 48 p.c. the beginning of lung maturation could be observed. In the pneumocytes type II we saw electron dense, homogenous granules which are precursors of lamellar bodies (figure $2 \mathrm{a}$ ).

In the pneumocytes of guinea-pig fetuses on day 53 p.c. there were both homogenous granules and lamellar bodies, that means an advanced stage of lung maturity (figure $3 \mathrm{a}$ ). The lungs of animals with a gestational age of 59 to 54 days p.c. are mature. A large number of lamellar bodies in the pneumocytes type II and also a secretion of surfactant into the alveolus is found (figure $4 \mathrm{a}$ ).

When comparing peak I, respectively peaks II and III in the NMR spectra with the electron micrographs, we could see that these peaks are present in all stages of the lung maturation, albeit at different intensities. It is remarkable that they are already present even before we find lamellar bodies in the pneumocytes type II or surfactant in the alveolus. 

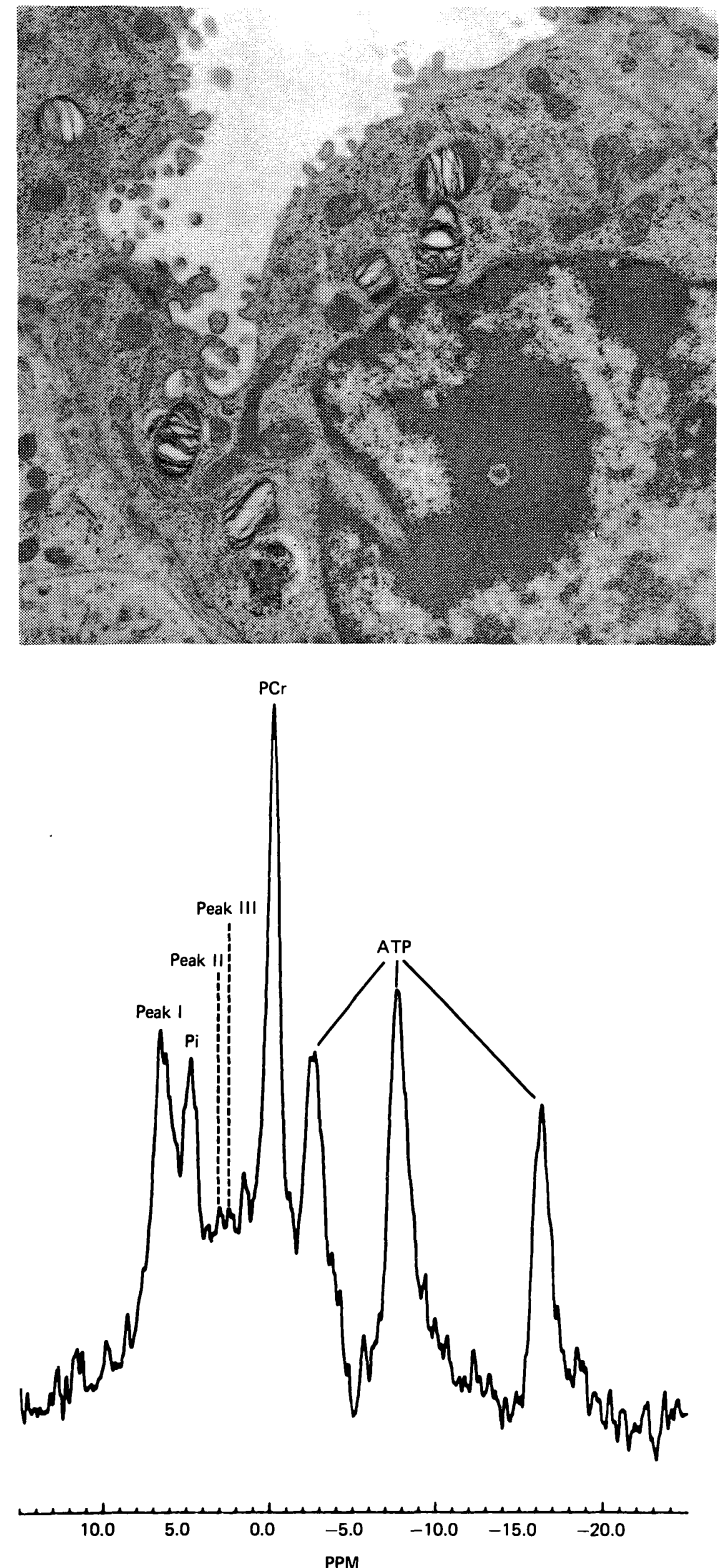

Figure 3. In-vivo spectrum of a 53 day-old guinea-pig fetus (b) and the associated electron microscopic results (a): homogenous granules and lamellar bodies are present in the pneumocyte type II (Magnification 16000:1)

\section{Discussion}

The chemical shift which appears at peak I - this peak is in the phosphomonoester region - is generally classified as sugar phosphate. However,

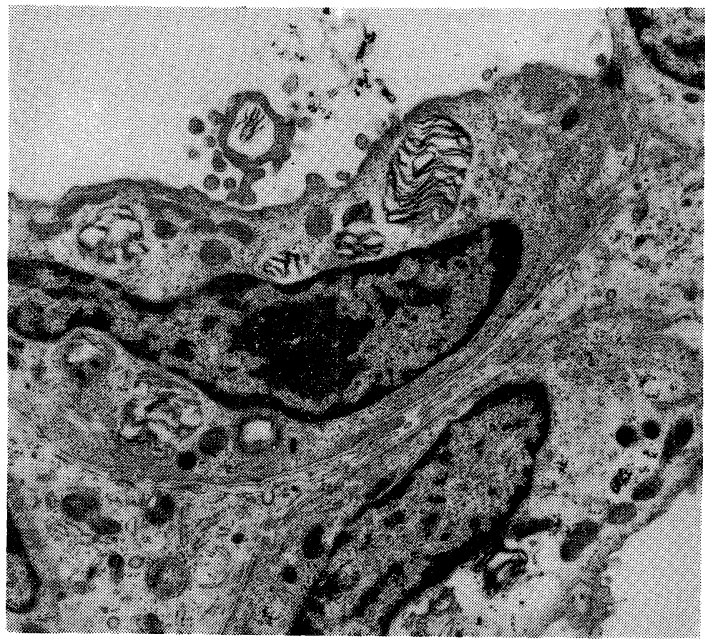

$\mathrm{PCr}$

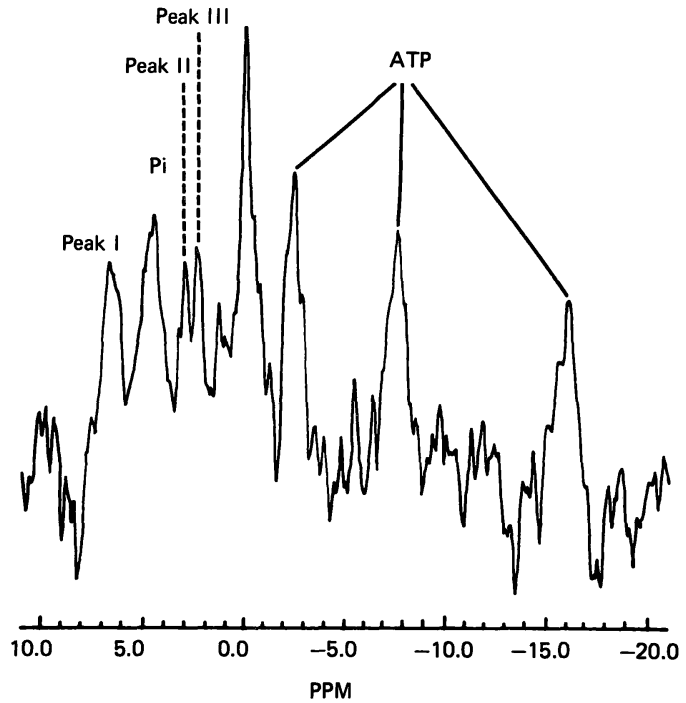

Figure 4. In-vivo spectrum of a guinea-pig fetus on day 62 p.c. (b) and the corresponding electron micrograph (a): fully developed lung maturity with a large number of lamellar bodies and already a secretion of surfactant in the alveolus (Magnification $16000: 1$ )

recently BRENTON et al. have been able to prove that this is often not the case [3]. They showed that in the brain this peak mainly represents phosphoethanolamin. From biochemical investigations in the fetal lung we know that phosphorylcholine is present in considerable concentrations $[4,7]$. Phosphorylcholine actually appears at this chemical shift value [1]. Hence the large peak $I$ in the 
phosphorous NMR spectra of the fetal lung is very likely attributable to phosphorylcholine which plays an important part in the biochemical pathway of the surfactant synthesis.

Peaks II and III appear in the diester region of the P31 NMR spectrum where, according to numerous investigations, the signals of phosphatidylcholine and other phospholipids are located [2, 6]. Taking the biochemical analyses of the fetal lung tissue into account, peaks II and III may represent phosphatidylcholine as well as the other phospholipids of the lung surfactant $[4,7]$. From the above mentioned facts, which are demonstrated in our tables and figures, we can see that peak I and also peaks II and III are present in the NMR in-vivo spectra, before the lamellar bodies in the pneumocytes type II are present. This means not only that the lecithin of the lamellar bodies and of the surfactant in the alveolus can be determined, but also with the help of NMR in-vivo spectroscopy, those phospholipids in the pneumocytes type II can be measured, which are present as precursors. However, it is possible that these are homogenous granules or lecithin found in the microsome fraction [5]. When we consider the intensity of peak I, we can see that the relative signal intensity increases with both advancing ges- tational age and also with advancing lung maturation. We should mention that our measurements were confined to a relatively small number of cases.

Furthermore we can say that with NMR in-vivo spectroscopy fetal lung lecithin can be directly measured. However up to now with this method it has not been possible to distinguish where the measured lecithin is located. The surfactant of the alveolus, the phosphatidylcholine of the lamellar bodies, of the homogenous granules or of the microsome fraction may contribute to this signal. As lamellar bodies are regarded as indicators of fetal lung maturity, up to the present time it has not yet been possible to predict how this technique may be used in the future for fetal lung maturation diagnostics. Nevertheless the direct measurement of fetal lung phospholipids is a promising tool for studying the course of fetal lung maturation and its promotion. Further combined investigations of phosphorous in-vivo spectroscopy of the fetal lung, electron microscopic analyses and extraction of the tissues and biochemical examinations are necessary to achieve the certain classification of the spectra found. This combined technique may open new avenues concerning lung development and maturation and their diagnostics in the future.

\section{Summary}

We have been successful in achieving phosphorus NMR in-vivo spectra of the fetal lung in an animal model. We used pregnant guinea-pigs with a gestational age of 45 to 65 days. The spectra were recorded on a Bruker tomograph (BMT 24/30) with a field strength of $2.35 \mathrm{~T}$. The spectra showed a typical pattern. After recording the animals were sacrificed and the lungs were prepared for electron microscopic examinations. In the spectra peaks were found which appeared to be phosphorylcho-

line and phosphatidylcholine. For one peak it could be observed that the relative signal intensity increased with increasing gestational age as well as with increasing lung maturity. This could not be observed for other peaks. So the lecithin of the surfactant in the tissue of the fetal lung appears to be directly accessible through phosphorus in-vivo NMR spectroscopy. The peaks found appear already before the lamellar bodies are present in the pneumocytes type II.

Keywords: Fetal lung maturity, medical resonance, surfactant.

\section{Zusammenfassung}

NMR in-vivo Spektroskopie in der fetalen Lunge beim Meerschweinchen

In einem Tiermodell ist es uns gelungen, Phosphor NMR in vivo Spektren der fetalen Lunge aufzuzeichnen. Wir verwendeten dazu schwangere Meerschweinchen mit einem Gestationsalter von 45 bis 65 Tage. Die Spektren wurden auf einem Bruker Tomographen (BNT 24/30) bei einer Feldstärke von 2.35 Tesla aufgenommen. Die Spektren zeigten ein charakteristisches Muster. Nach der
Messung wurden die Tiere getötet und die fetalen Lungen wurden für die elektronmikroskopischen Untersuchungen fixiert. Typische in den Spektren gefundene Peaks scheinen Phosphorylcholin und Phosphatidylcholin darzustellen. Bei einem dieser Peaks konnte beobachtet werden, daß die relative Signalintensität sowohl mit zunehmenden Gestationsalter als auch mit elektronenmikroskopisch festgestellter zunehmender Lungenreife ansteigt. Dieses traf für den zweiten Peak nicht zu. 
Es scheint somit, daß die "surfactant" im Gewebe der fetalen Lunge mit der Phosphor in-vivo NMR Spektroskopie direkt meßbar wird. Die gefundenen Peaks treten bereits auf, bevor lamellar bodies in den Pneumozyten des Typs II gesehen werden.

Schlüsselwörter: Kernspinresonance, Lungenreife, Surfactant.

\section{Résumé}

Spectroscopie in-vivo du poumon fetal chez le cochon d'Inde

Nous avons réussi à réaliser les spectres in-vivo par RMN du phosphore du poumon fotal sur un modèle animal.

Nous avons utilisé des cochons d'Inde gravides d'un âge gestationnel de 45 à 65 jours. Les spectres ont été enregistrés sur un tomographe Bruker (BMT 24/30) avec une intensité de champs de 2,35 $\mathrm{T}$. Les spectres montrent un modèle typique. Après enregistrement, les animaux étaient sacrifiés et les poumons étaient préparés pour des examens en microscopie électronique. On a trouvé dans les spectres des pics qui paraissent correspondre à la phosphorylcholine et la phosphatidylcholine. On a pu observer pour un pic que l'intensité du signal relativ augmente avec l'âge gestationnel de même qu'il augmente avec la maturation pulmonaire. On n'a pas du observer celà pour les autres pics. Ainsi, la lécithine du surfactant dans les tissus pulmonaires fotaux apparait comme étant directement accessible par spectroscopie RMN du phosphore in vivo.

Les pics apparaissent déjà avant l'apparition des corps lamellaires au sein des pneumocytes de type II.

Mots-clés: Maturité pulmonaire fotale, résonnance médicale, surfactant.

\section{References}

[1] Barany M, T GloneK: Identification of diseased states by Phosphorus-31 NMR. In: Phosphorus 31NMR, Academic Press, Orlando 1984

[2] BERDEN JA, RW BARKER, GK RADDA: NMR studies on phospholipid bilayers - some factors affecting lipid distribution. Biochim Biophys Acta 375 (1975) 186

[3] Brenton DP, PJ Garrod, S Krywawyh, EOR REYNOLDS, HS BACHELARD, DW COX, PG MORRIS: Phosphoethanolamine is major constituent of phosphomonester peak detected by $31 \mathrm{P}$ NMR in newborn brain. Lancet I: (1985) 115

[4] Hollingsworth M, AM Gilfillan: The pharmacology of lung surfactant secretion. pharmacol Rev 36 (1984) 69

[5] JOBE A: The labeling in subcellular fractions of rabbit lung. Biochem Biophys Acta 489 (1977) 440
[6] London E, GW Feigenson: Phosphorus NMR analysis of phospholipids in detergents. J Lipid Res 20 (1979) 408

[7] Perelmann RH, MJ Engle, PM Farrell: Perspectives on fetal lung development. Lung 159 (1981) 53

Received April 18, 1988. Accepted August 2, 1988.

Dr. Klaus Langner Institute of Perinatal Medicine The Free University of Berlin Frauenklinik Neukölln

Mariendorfer Weg 28

D-1000 Berlin 44

West Germany 